\title{
SHIFT IN THE ANNUAL GROWTH CYCLE OF GRAPEVINES (VITIS VINIFERA L.) IN WEST HUNGARY
}

\author{
KovÁCS, E. ${ }^{*}-$ PuskÁs, J. ${ }^{2}-$ POZSGAI, A. ${ }^{1}-$ KOZMA, K. ${ }^{3}$ \\ ${ }^{I}$ Doctoral School of Environmental Sciences, ELTE Eötvös Loránd University \\ Pázmány P. sétány 1/A, H-1117 Budapest, Hungary \\ ${ }^{2}$ Savaria Department of Geography, ELTE Eötvös Loránd University \\ Károlyi G. tér 4, H-9700 Szombathely, Hungary \\ ${ }^{3}$ Department of Environmental Engineering, Széchenyi István University \\ Egyetem tér 1, H-9026 Györ, Hungary \\ *Corresponding author \\ e-mail: kovacserik19@gmail.com \\ (Received $2^{\text {nd }}$ Jan 2018; accepted $7^{\text {th }}$ Mar 2018)
}

\begin{abstract}
Regional climate change has noticeable influence on grape and wine production in West Hungary. Sopron and Zala wine-growing regions are among the potential winners of the climate change, previously rather unsuitable for viticulture. Over the past 30 years, the minimum and maximum temperatures significantly increased, the precipitation decreased, nevertheless, the convective precipitation increased by 14 days during the growing season. Each climate indicator has changed between 1986 and 2015 compared to the previous 30 years (1956-1985). One of the effects of climate change is a significant shift in the annual growth cycle of grapevines (phenological phases). Budbreak begins nearly 8 days earlier, flowering 7 days and the veraison 8 days, while the harvest has been shifted to a date 11 days respect to the previous period. The time between the budbreak and the flowering has shortened by 4.5 days.
\end{abstract}

Keywords: climate change, agroclimate, growing-season, phenology, Carpathian Basin

\section{Introduction}

Climate change is one of the most determinative challenges in the $21^{\text {st }}$ century and protection against the extremities. The decreasing precipitation and the increasing temperatures have several visible signs both in Europe and in Hungary during the growing season and dormancy period (Gaál et al., 2012; Cook and Wolkowich, 2016).

Since the middle of the $20^{\text {th }}$ century, the border of ideal wine-producing areas in Europe has been pushed to the North roughly by 50-100 km (Bowen et al., 2004; Mozell and Thach, 2014), which, by the middle of the $21^{\text {st }}$ century, means further significant expansion to the North (Hoffmann et al., 2007). Areas where the growing of wine grape (Vitis vinifera L.) of good quality with high sugar content was previously unimaginable, are now becoming suitable (e.g. North Germany, Baltic countries, etc.).

Mainly, the domesticated plants react to the changed circumstances sensitively in temperate climate regions, therefore grapevine is one of the most notable indicators of climate change (Durack et al., 2014).

For the production, it is important to take into consideration the balance of soilclimate-variety in all cases (Fraga et al., 2013). As a result of the climatic change such balance may waver in the negative or positive direction (Fraga et al., 2014), therefore it is particularly important to plant such grape varieties and their clones, which are able to adapt to the changes (Grzeskowiak et al., 2013; Ignaciuk and Mason-D’Croz, 2014). 
The main objective of our research was to examine the phenological response of grapevine to the climate change in West Hungary over the past 30 years.

\section{Material and method}

\section{The study area}

The research and the observation are performed in the area of the Sopron and Zala wine-growing regions situated on the western part of the Carpathian Basin.

Most parts of the area of Sopron wine region belongs to Sopron Mountains and Köszeghegyalja, while most part of Zala wine-growing region belongs to EgerszegLetenye Hills, Zalaapáti Ridge, Lenti Hills and Kerkamente (Fig. 1).

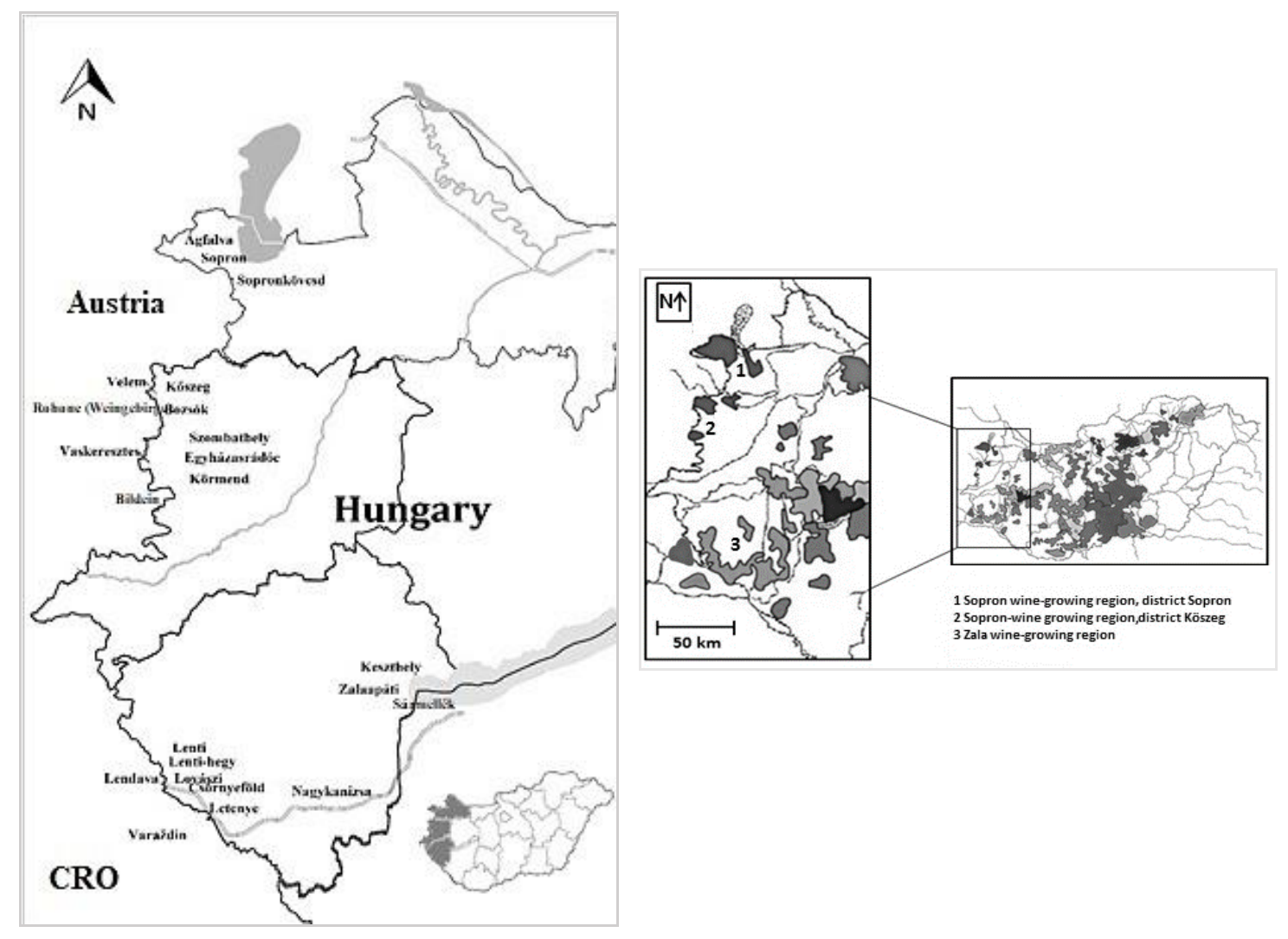

Figure 1. The used meteorological stations (left) and the studied wine-growing regions (right)

The western areas are characterised by pseudo-gley forest soil, the eastern areas by luvisol, while on the northern part of Zalaapáti Ridge we can find alluvial soil, which is rich in water supply, however its quality is not very good. (Dövényi, 2010). The soil of both wine regions is cohesive, Zala wine-growing region is characterised by slight slope grape hills, while in Köszeghegyalja (and Vas Hills) steep slopes are frequent, often with eroded soil, which are free from extreme, strong frost.

The northern part of the Sopron wine-growing region belongs to the moderately cool-moderately dry climate region, while Zala wine-growing region and Köszeghegyalja belong to the moderately cool-moderately humid climate category (Péczely, 2002). 
The annual average temperature is $9-9.3{ }^{\circ} \mathrm{C}$ in the area of the Sopron district of the Sopron wine region, 8-9 ${ }^{\circ} \mathrm{C}$ in Köszeghegyalja, $9.8-10{ }^{\circ} \mathrm{C}$ in the area of the Zala winegrowing region (Justyák, 1998).

The annual precipitation is around $750-770 \mathrm{~mm}$, a bit more than the quantity suitable for the needs of the grapevine, but not so outstanding as in some French, German or Swiss wine regions.

The rainiest area is Köszeghegyalja, the driest is Zalaapáti Ridge. The number of hours of sunshine is around 1800-2000 h, which increases from north towards south.

In the case of the wine grape, while analysing the climate data from the temperature aspect, the value of the active amount of heat (Growing Degree Days) during the growing season must be taken into consideration (the additional heat sum above $10{ }^{\circ} \mathrm{C}$, when certain life processes of the plants are starting). The average of the GDD during the growing seasons of previous 30 years (1956-1985) amounts to $1120-1170{ }^{\circ} \mathrm{C}$ in the studied area, which according to our calculations, went up to an average of $1200{ }^{\circ} \mathrm{C}$ between 1986 and $2015(\mathrm{sd}=42.31)$.

Huglin-index (Heliothermal Index of Huglin) has been developed for the winegrowing regions, which is a refined and modified warm bioclimatic index (Huglin, 1986), which gives the amount of the number of the days when the average temperature is higher than $+10{ }^{\circ} \mathrm{C}$ between $1^{\text {st }}$ of April and $30^{\text {th }}$ of September, considering the changing photoperiod between $40-50^{\circ}$ latitude (Hoppmann, 2010).

On the Northern Hemisphere the calculation of the Huglin-index is the following (Eq. 1, Huglin, 1986; Maaß and Schwab, 2011):

$$
H I=K \cdot \sum_{01.04}^{30.09} \frac{\left(T_{\text {med }}-10\right)+\left(T_{\max }-10\right)}{2}
$$

$\mathrm{T}_{\text {med }}=$ daily air temperature $\left({ }^{\circ} \mathrm{C}\right)$

$\mathrm{T}_{\max }=$ daily maximum air temperature $\left({ }^{\circ} \mathrm{C}\right)$

Base temperature $=10^{\circ} \mathrm{C}$

$\mathrm{K}=$ length of day coefficient (varying from $40^{\circ}=1.02$ to $50^{\circ}=1.06$ ), it was calculated by 1.05

According to our calculations, during the period 1986-2015, the value of the Huglinindex fluctuates between $1950-2100{ }^{\circ} \mathrm{C}$ in the studied area. The annual data show significantly increasing trend $(\mathrm{p}<0.01)$ (Kovács et al., 2017).

Hungary is located on the northern border of the grape productivity, because most of the grape varieties are resistant to frost only up to $-15^{\circ} \mathrm{C}$. Due to such circumstance, the grape could be efficiently grown only by certain cultivation practices and in the appropriate places of production (Kriszten, 1999).

On the bases of the Huglin-index, Blaufränkisch, Müller-Thurgau, Pinot noir, Pinot Blanc, Chardonnay, Cabernet franc etc. can be grown efficiently in the area of the wine regions (Apró, 2016; Puskás and Károssy, 2013).

If the temperature continues to rise in the future during the growing season in the wine-growing regions, it will be worth cultivating more temperature sensitive wine grape varieties. On the bases of the homogenised average of 30 years (1986-2015), most of the rainfalls occur in the area from May to the end of August, nearly $350 \mathrm{~mm}$. This period of the growing season starts with flowering and lasts until ripening. Thus, the proper quantity of precipitation is very important for each year, in order to ensure that 
the plant can use the adequate quantity of humidity for building of the cells (Mesterházy et al., 2014).

The studied wine-growing regions belong to regions, which are not exposed to the danger of drought (Bussay et al., 1999). Drought is the long-lasting lack of precipitation combined with excessive heat that is the daily maximum temperature exceeding $25{ }^{\circ} \mathrm{C}$ and the soil moisture falling below $20 \%$ (Keddy, 2007).

The climate conditions of the wine-growing regions suggest that the area is ideal for the northern wine grape varieties, as well as for the varieties needing more precipitation, while it is less favourable for the Mediterranean varieties or those requiring little precipitation. The latter can be efficiently cultivated where the value of the Huglin-index is at least $2150-2200{ }^{\circ} \mathrm{C}$, the number of sunny hours is more than $2100-2200 \mathrm{~h}$ and the precipitation in the growing season does not exceed $300 \mathrm{~mm}$ (Clarke and Rand, 2001).

Owing to the climate of the wine-growing regions, the Sopron red wines have a fresh character and flavour, which recall mainly the red berries. The most growers are specialised in the production of the red wines. The white grape varieties are rare in Sopron, hardly accessible, but it is frequent in Zala. There are red wine blendings in the wine-growing region, in most cases their base is typically Blaufränkisch, which may be completed by the wines of the cabernet varieties, by Merlot, Zweigelt, recently more and more frequently by Syrah.

\section{Tools and methods}

A specifically executed phenological research has been started at the wineries in the Zala and the Sopron wine-growing regions at the beginning of the years 2000. The five most frequent wine grape varieties are examined (Zala wine region: Pinot Gris, Welschriesling, Müller-Thurgau, Zweigelt, Királyleányka; Sopron wine region: Blaufränkisch, Zweigelt, Chardonnay, Cabernet Sauvignon and Green Veltliner) on the plantation of 21 winegrowers.

For the purposes of the research, the data of the calibrated meteorological stations were used, which are located near and in the area of the Sopron and Zala wine-growing regions. Among them the ones situated in Szombathely, Körmend, Köszeg, Nagykanizsa, Iklódbördőce, Keszthely, Zalaegerszeg, Sármellék belong to the Hungarian Meteorological Service (OMSZ).

We have our own calibrated private stations installed in districts of Zala winegrowing region, in Csörnyeföld, Letenye, Nagykanizsa, Lovászi, Lenti, Lentihegy, Zalaapáti, Keszthely, Lendva (Lendava) and Varasd (Varaždin), as well as in Köszeghegyalja-Vaskeresztes in the Sopron wine-growing region, in Sopronfalva, Ágfalva, Köszeg (Köszegfalva), Velem, Szombathely, Vaskeresztes and Bozsok and near to the Austrian-Hungarian border in Burgenland (Fig. 1).

The examination of the general climate parameters (annual average temperature, monthly average temperature, annual precipitation, monthly precipitation) is not sufficient for the description of the conditions of a certain production place because they only show a superficial character. This is the reason why special parameters and indicators have been created (e.g. summer days $\mathrm{T}_{\max }>25{ }^{\circ} \mathrm{C}$, hot days $\mathrm{T}_{\max }>30{ }^{\circ} \mathrm{C}$, heat days $\mathrm{T}_{\max }>35^{\circ} \mathrm{C}$, Photosynthesis Critical Point $\mathrm{T}_{\max }>38^{\circ} \mathrm{C}$, etc.), many of which are used in agro-climatic researches on the whole, and some indicators are applied specifically for the examination of particular production places or wine regions. 
A statistical "cleaning" was made on the received data, then homogenization and interpolation were executed.

Regarding the change of the climate parameters, the analysed period is 1986-2015 (the examination results of the phenological thread are not exact when being "laid" between 1981 and 2010). Budbreak, flowering, veraison and harvest were investigated among the phenological phases.

Since the efficient growing of the grape absolutely requires the knowledge of the soil (type, albedo, temperature), the climate, as well as the gradient, the exposure and the roughness of the slope, the examination of the phenological processes of the grape was personally executed during the budbreak 2 or 3 times a week, during the flowering day by day, from the veraison until the beginning of the harvest once a week and during the harvest several times a week by the assistance of the growers.

In the studied area, most of all in Köszeghegyalja and in the area of Vas Hills, Kerkamente, Muramente, the formation of smaller units possessing a peculiar microclimate often occurs, even within small areas, it may happen that the risk of the spring frost is different in two respective vineyards. For the estimation of the risk of the spring frost, the most suitable indicators are the following:

$\mathrm{T}_{\min } 4 \mathrm{i} 5=$ average minimum temperature in April and May, $2 \mathrm{~m}$ above ground

$\mathrm{T}_{\min }+54 \mathrm{i} 5=$ average minimum temperature of April and May, $5 \mathrm{~cm}$ above ground

$\mathrm{T}_{\min }+504 \mathrm{i} 5=$ average minimum temperature of April and May, $50 \mathrm{~cm}$ above ground

Due to the lack of data, the last two indicators have been analysed with respect of the period after 2001.

The sugar content was examined too. For this test, the winegrowers give us data and a database was created by us about the cyclonic and anticyclonic days, 60 days preceding the harvests, based on Péczely's large-scale weather types (Makra et al., 2007).

\section{Results}

\section{Climate parameters}

In the viticulture, there are several climate indicators and their combinations, which are applied for the description of the production places and for the expression of the needs of the grape. They are used in examinations possessing series of data from several decades, on the one hand for the definition and for the demonstration of the climatic change, on the other hand for the description of the individual plots (Hlaszny, 2012).

In the course of the analysis of the indicators, as functions of the individual weather parameters, weather parameters were defined, which can be directly connected to the character of the vegetal response (Carter et al., 2007). Analysis of the climatic indicators plays a significant role in the methodology of the impact assessment of the climatic change (Hlaszny, 2012). By means of the information resulting from the change of the individual indicators, so conclusions can be drawn regarding the growing conditions in the future (Hlaszny, 2012).

The successful growing of the grape is determined also by the hours of sunshine, but most of all by the temperature and the precipitation.

Between 1956 and 2015 the annual average temperature increased by $1.1{ }^{\circ} \mathrm{C}$ in the Sopron and Zala wine-growing regions, by $1.2{ }^{\circ} \mathrm{C}$ in the Zala wine-growing region and by $0.9^{\circ} \mathrm{C}$ in the Sopron wine-growing region. The acceleration of the increase of the 
temperature can be observed from the second half of the years 1980. Between 1986 and 2015 the increase of the temperature is significant, it reached $1.47{ }^{\circ} \mathrm{C}\left(1.38{ }^{\circ} \mathrm{C}\right.$ in Sopron and $1.55^{\circ} \mathrm{C}$ in Zala wine-growing region) (Fig. 2). In the field of the studied regions among the ten hottest years of the period 1956-2015, seven were measured after 1990. The four years with the highest average temperature were $2015\left(11.9^{\circ} \mathrm{C}\right), 2014$ $\left(11.6^{\circ} \mathrm{C}\right), 2012\left(11.2^{\circ} \mathrm{C}\right)$ and $2011\left(11.1^{\circ} \mathrm{C}\right)$.
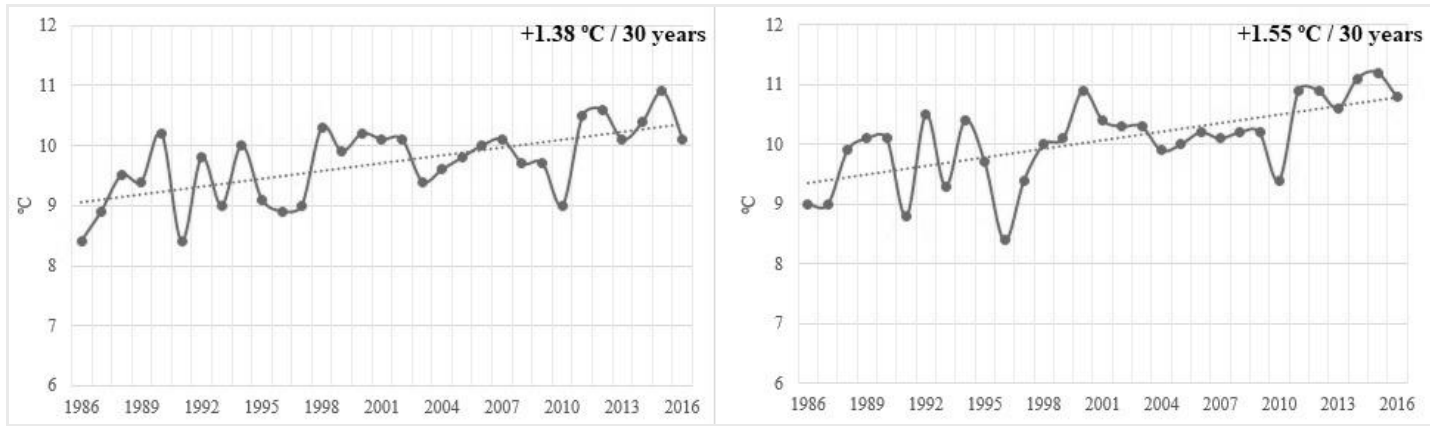

Figure 2. Change in mean temperature (avg. $+1.4{ }^{\circ} \mathrm{C} / 30$ years). Sopron wine-growing region (left), Zala wine-growing region (right)

If the changes in the temperatures were analysed also by seasons, it can be seen more vigorous modifications in case of some seasonal temperature average. The average temperature has significantly increased in spring, summer and autumn.

The average temperature of the growing season $\left(1^{\text {st }}\right.$ April $-31^{\text {st }}$ October $)$ increased by $2.8{ }^{\circ} \mathrm{C}$, while in the dormancy period by $1.3{ }^{\circ} \mathrm{C}$, during the 30 days preceding the budbreak $\left(15^{\text {th }}\right.$ March $-15^{\text {th }}$ April) by $1.8{ }^{\circ} \mathrm{C}$, before the blooming from $15.1^{\circ} \mathrm{C}$ to $16.4{ }^{\circ} \mathrm{C}$, during the time of the blooming from $16.4{ }^{\circ} \mathrm{C}$ to $18.1{ }^{\circ} \mathrm{C}$, before the veraison by $2.4^{\circ} \mathrm{C}$, to $20.8^{\circ} \mathrm{C}$ (Fig. 3).

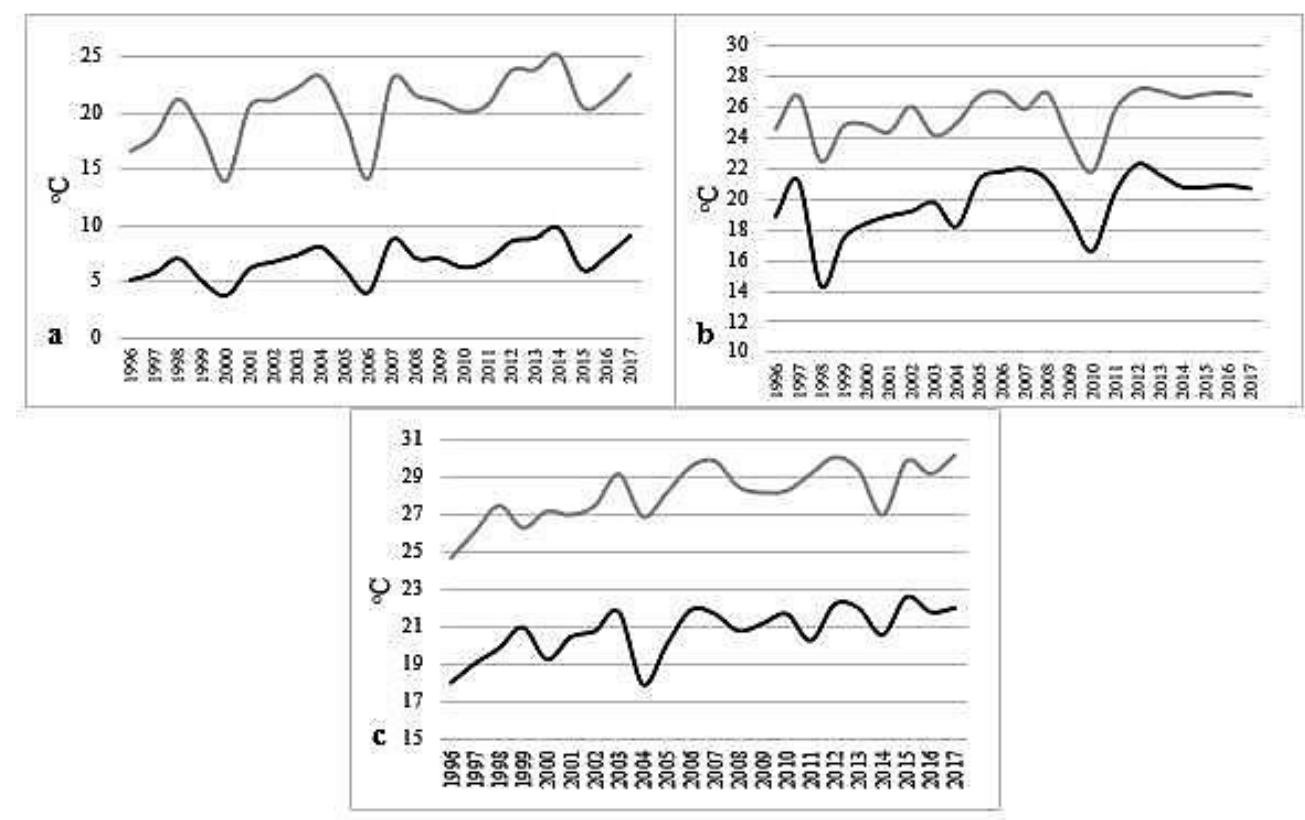

Figure 3. Mean and maximum temperature trends, 30 days preceding the budbreak (a), 20 days preceding the blooming $(b)$ and 15 days preceding the veraison (c) 
During the time of the harvest the maximum and minimum temperatures have increased considerably, the former is higher by $2.2{ }^{\circ} \mathrm{C}$ than the previous average, the latter by $2.0^{\circ} \mathrm{C}$. Although the change is not significant, but the number of late-spring frost days $\left(\mathrm{T}_{\min } 4 \mathrm{i5}\right)$ has increased by 4 days, in the meantime the increase in the number of the summer days $\left(\mathrm{T}_{\max }>25^{\circ} \mathrm{C}\right)$ is significant.

For the smooth process of the vegetation cycle of the grape, it is necessary to summarize the temperature impacts, which affected the plant. This is the so-called active amount of heat.

It can be obtained the value of the amount of active heat, if the value of temperature is above $+10{ }^{\circ} \mathrm{C}$ (biological $0{ }^{\circ} \mathrm{C}$ ) during the growing season. On the bases of the above it can be concluded, that the amount of active heat values has considerably changed in the studied wine regions since 1986. In the Sopron district of the Sopron wine-growing region from $1120^{\circ} \mathrm{C}$ to $1240{ }^{\circ} \mathrm{C}$, in the area of the district Köszeg-Vaskeresztes from $1090{ }^{\circ} \mathrm{C}$ to $1220^{\circ} \mathrm{C}$, in the Zala wine region from $1110{ }^{\circ} \mathrm{C}$ to $1290{ }^{\circ} \mathrm{C}(\mathrm{sd}=89.12)$ (Fig. 4$)$.

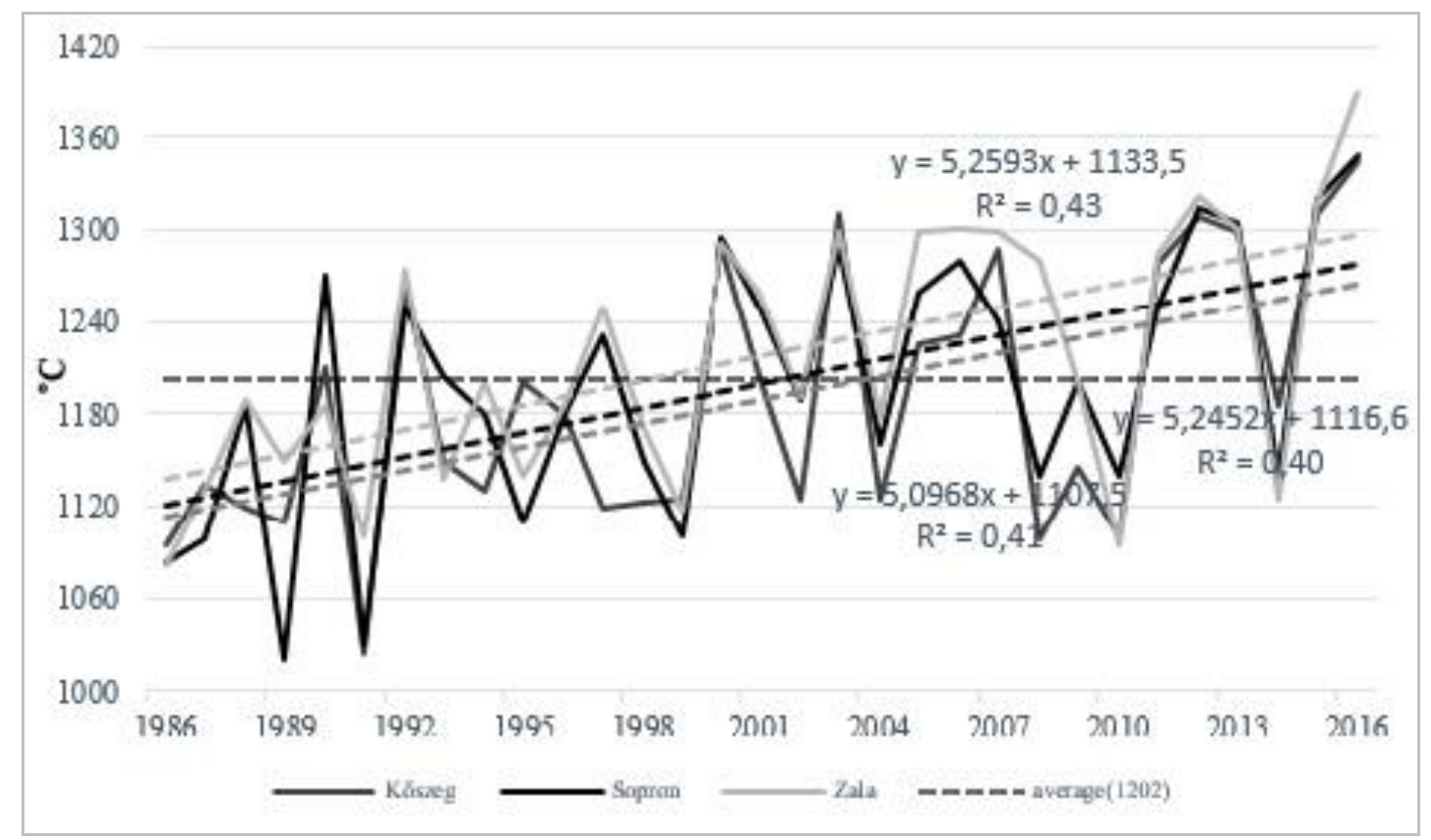

Figure 4. Value of the amount of active heat in the studied wine-growing regions since 1986

The number of intense heat days $\left(\mathrm{T}_{\max }>35{ }^{\circ} \mathrm{C}\right)$ and hot days $\left(\mathrm{T}_{\max }>30{ }^{\circ} \mathrm{C}\right)$ has increased significantly in the studied region, nearly by $250-300 \%$. The high number itself of intense heat days and hot days may not cause any problem in viticulture (in Sicily the number of the annual of intense heat days amounts to 65-70 days) (Orlandi et al., 2009).

Such condition means a danger only if suitable ways of protection are not available and the hot weather lasting for several days may result in the damage of the fresh green sprouts, the flowers, the fruit tubers and the foliage or in case the temperature is durably above $38{ }^{\circ} \mathrm{C}$, the photosynthesis of the grapevine may slow down or may even stop 
(Frankel, 2014). The average number of days with temperature above $38{ }^{\circ} \mathrm{C}$ is 1.5 day/year in the period 1986-2015.

According to the water needs, $88 \%$ of the water and moisture absorbed during the growing season is used by the grapevine in the phases of the maturation and ripening, while only $12 \%$ at the beginning of the growing season, from the budbreak until the end of the flowering (Currle et al., 1983), therefore the precipitation, as indicator is relevant in the second part of the growing season most of all.

The annual precipitation has not changed considerably in the studied area.

Considering the phenological researches, it is important to examine the change of the precipitation in the growing season. In the period between $1^{\text {st }}$ of April until $31^{\text {st }}$ of October the quantity of fallen rain has decreased by $21 \%$ (it is most significant in August and September), while it has increased by $23 \%$ in the dormancy period.

Between the veraison and the period preceding the harvest, the fallen rain has decreased by $25 \%$ nearly, while the number of days with heavy precipitation $\left(\mathrm{R}_{\text {day }}>20 \mathrm{~mm}\right)$ has increased from 5 to 11 days.

As previously was mentioned, the grapevine can be grown successfully in case the precipitation does not exceed $300 \mathrm{~mm}$ in the growing season. In the studied wine regions, such value is even slightly higher, $360 \mathrm{~mm}$. Besides the quantity of the precipitation, its type is also important from the point of view of the productivity. This is the point where we need to mention the snowy days.

The number of days with snow cover (the ground is covered by snow) is a relevant factor, as the snow while melting, filtrates slowly into the soil, consequently the moisture reaches the deeper layers of the ground as well, which is mainly necessary for older plants with deep roots. The roots have no dormancy period (Herbst and Herbst, 2003). In case the temperature of the soil does not fall below $5-6^{\circ} \mathrm{C}$, the growth of the root is continuous both vertically and horizontally. To accomplish this, the grapevine needs moisture. The winter precipitation of solid form, by its "isolating" character, protects the young stems from the strong frost (Lobell et al., 2008). Change in each important Vitis indicator is shown in the Table 1.

The snow cover of the Sopron and Zala wine-growing region is 43 days on the bases of the average measured in the period 1956-1985, which has considerably dropped in the past 30 years, by 21 days.

\section{Early phenological responses of grapevines}

Considering the time of the budbreak begins 8 days earlier, the flowering also begins 7 days earlier (as for Királyleányka and Green Veltliner 12 days) (Fig. 5), the time between the budbreak and the flowering has shortened by 4 days, which is not significant. This is the time when the buds that will become next year's crops begin to form.

The total time of the flowering has shortened by 5 days. Although the flowering happens earlier, the massive proportion (55-60\%) is reached 2-3 days later (Fig. 6).

The stage of fruit set follows flowering almost immediately, climate and the health of the vine play an important role with low humidity, high temperatures and water stress having the potential of severely reducing the amount of flowers that get fertilized (Mullins et al., 1992).

It is observed by us that varieties like Merlot, Syrah and Cabernet Franc react sensitively to the very high temperatures and very low precipitation. These grape varieties are prone to the abnormal fruit set, if the weather too extreme. 
Table 1. Change in each important Vitis indicator in Sopron and Zala wine-growing regions

\begin{tabular}{|c|c|c|c|}
\hline Indicator & 1956-1985 & 1986-2015 & $\begin{array}{c}\text { Standard deviation } \\
(1986-2015)\end{array}$ \\
\hline Mean January temperature ${ }^{\circ} \mathrm{C}$ & -0.8 & 0.6 & 0.4 \\
\hline July mean temperature ${ }^{\circ} \mathrm{C}$ & 19.4 & 21.2 & 1.8 \\
\hline $\begin{array}{c}\text { Growing season mean } \\
\text { temperature(01.04. }-31.10)^{\circ} \mathrm{C}\end{array}$ & 15.2 & 17.9 & 1.4 \\
\hline $\begin{array}{c}\text { Growing season maximum temperature } \\
(01.04 .-31.10)^{\circ} \mathrm{C}\end{array}$ & 23 & 25.2 & 1.7 \\
\hline $\begin{array}{l}\text { Growing season minimum temperature } \\
(01.04 .-31.10)^{\circ} \mathrm{C}\end{array}$ & 7.4 & 9.5 & 0.9 \\
\hline $\begin{array}{c}\text { Harvest time maximum } \\
\text { temperature }(15.08 .-15.10){ }^{\circ} \mathrm{C}\end{array}$ & 22.2 & 25.4 & 1.1 \\
\hline $\begin{array}{l}\text { Cool night index } \\
\text { (September) }{ }^{\circ} \mathrm{C}\end{array}$ & 10.2 & 10.6 & 0.5 \\
\hline $\begin{array}{c}\text { Summer rainfall } \\
(01.06 .-31.08) \mathrm{mm}\end{array}$ & 271 & 248 & 64 \\
\hline $\begin{array}{c}\text { Hot days } \\
\left(\operatorname{Tmax}>30^{\circ} \mathrm{C}\right) \text { day }\end{array}$ & 14 & 22 & 5 \\
\hline $\begin{array}{c}\text { Frost days } \\
\left(\text { Tmin }<0{ }^{\circ} \mathrm{C}\right) \text { day }\end{array}$ & 103 & 84 & 21 \\
\hline $\begin{array}{l}\text { Vitis frost days } \\
\left(\text { Tmin }<-8^{\circ} \mathrm{C}\right) \text { day }\end{array}$ & 53 & 32 & 6.5 \\
\hline $\begin{array}{l}\text { Extreme frost days } \\
\left(\text { Tmin }<-15^{\circ} \mathrm{C}\right) \text { day }\end{array}$ & 16 & 8 & 4.5 \\
\hline $\begin{array}{l}\text { Photosynthesis critical point } \\
\left(\text { Tmax }>38.5^{\circ} \mathrm{C}\right) \text { day }\end{array}$ & 1 & 2 & 1.5 \\
\hline $\begin{array}{c}\text { Huglin-index } \\
(01.04 .-30.09)^{\circ} \mathrm{C}\end{array}$ & $1890-1990$ & $1950-2100$ & 85 \\
\hline $\begin{array}{c}\text { Bloom period precipitation } \\
(15.05-30.06) \mathrm{mm}\end{array}$ & 85 & 74 & 21.14 \\
\hline $\begin{array}{l}\text { Ripening period precipitation } \\
(15.08-15.10) \mathrm{mm}\end{array}$ & 141 & 115 & 38.59 \\
\hline $\begin{array}{c}\text { Growing season precipitation } \\
(01.04 .-31.10) \mathrm{mm}\end{array}$ & 402 & 360 & 68.87 \\
\hline $\begin{array}{l}\text { Precipitation before Veraison } \\
(01.07 .-15.07) \mathrm{mm}\end{array}$ & 21 & 16 & 8.9 \\
\hline $\begin{array}{l}\text { Snow-covered days } \\
\text { (at least } 5 \mathrm{~cm} \text { ) day }\end{array}$ & 24 & 18 & 7 \\
\hline $\begin{array}{c}\text { Dry days } \\
(\text { Rday }<0.1 \mathrm{~mm})(01.08-31.10) \text { day }\end{array}$ & 19 & 26 & 11 \\
\hline $\begin{array}{c}\text { Gladstones frost index } \\
\mathrm{SFIg}=\left[\left(\mathrm{AT}_{\max }+\mathrm{AT}_{\min }\right) / 2\right] \min \mathrm{T}_{\min }\end{array}$ & 13.22 & 12.18 & 6.4 \\
\hline $\mathrm{T}_{\min } 4 \mathrm{i} 5^{\circ} \mathrm{C}$ & 3.1 & 2.9 & 0.96 \\
\hline $\mathrm{T}_{\min }+54 \mathrm{i} 5^{\circ} \mathrm{C}$ & - & 2.1 & 1.18 \\
\hline $\mathrm{T}_{\min }+504 \mathrm{i} 5^{\circ} \mathrm{C}$ & - & 2.4 & 1.25 \\
\hline
\end{tabular}




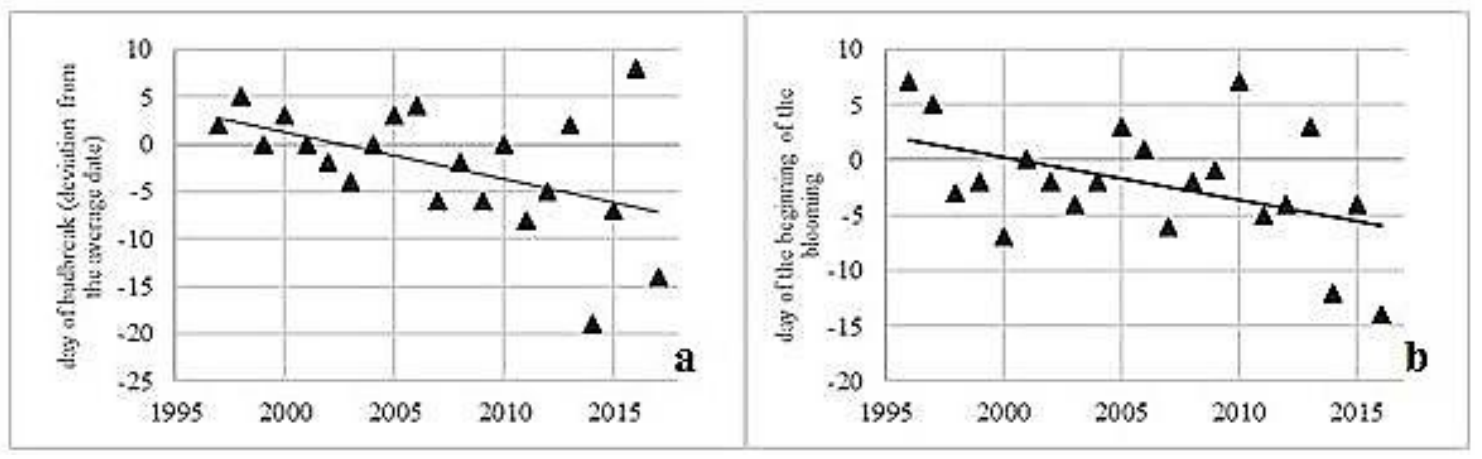

Figure 5. Day of budbreak (a) and blooming (if at least $10 \%$ of flowers are observable) (b) since 1996

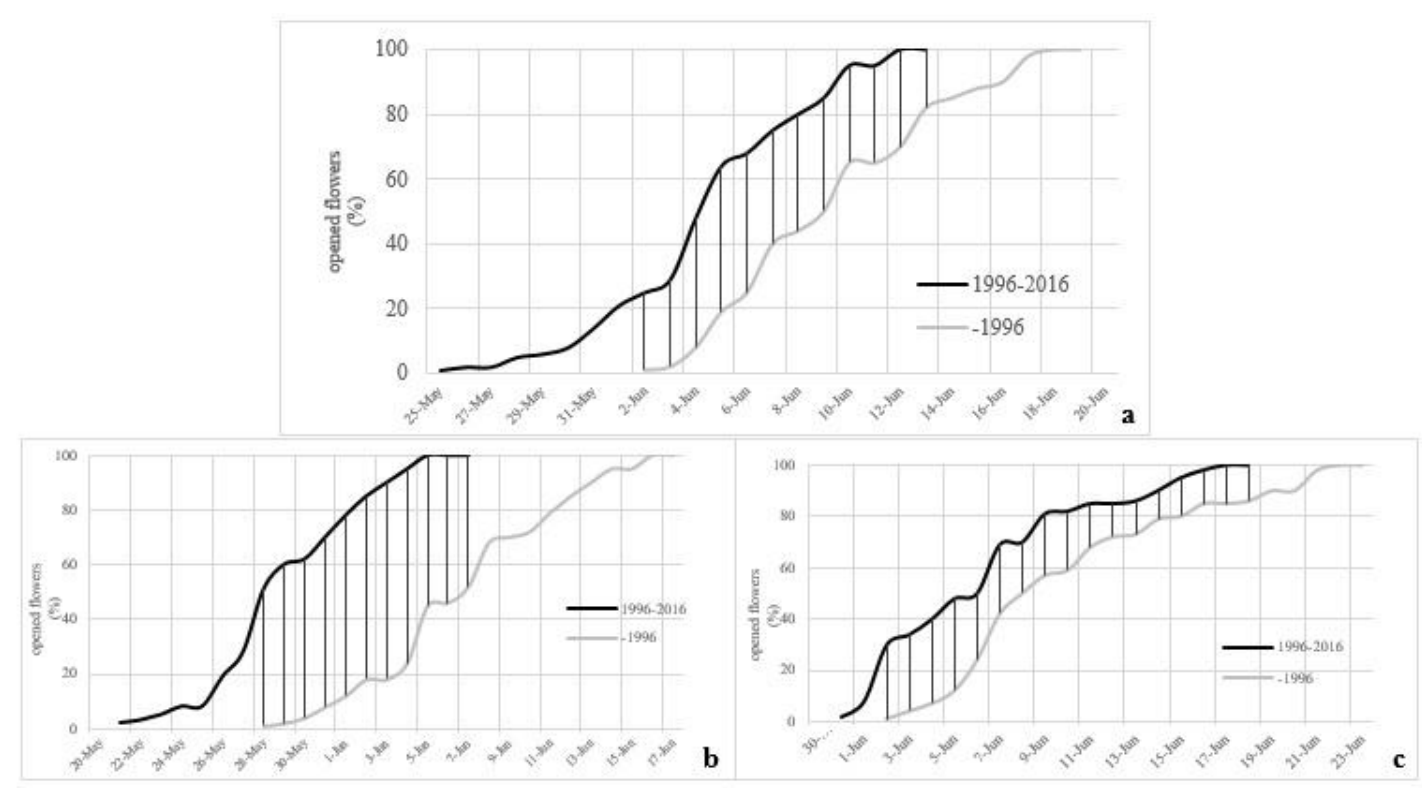

Figure 6. Change in the processes of the flowering (a: all varieties, $b$ : Merlot, c: Pinot Gris) in Sopron and Zala

\section{Veraison and harvest}

The next phenological mainstage is the veraison. The berries are green and hard to the touch. In the middle of this stage, the building of the cells speeds up. The ripening process starts around the middle of July if the temperatures are adequate in the field of the studied region.

No considerable change has been observed concerning the maturation, however during the time of the veraison we have observed, most of all in case of the red varieties. This phenological stage is pushed 13 days earlier for Merlot and 10 days earlier for Zweigelt.

The emergence of the colours is faster than before. Harvests happens 11 days earlier respect to the previous period (1971-1995) (Fig. 7), the number of anticyclonic days has increased by $12 \%$ during the period 1986-2015, between 1996 and 2017, such increase reached $19 \%$ in the 60 days preceding the harvests. 


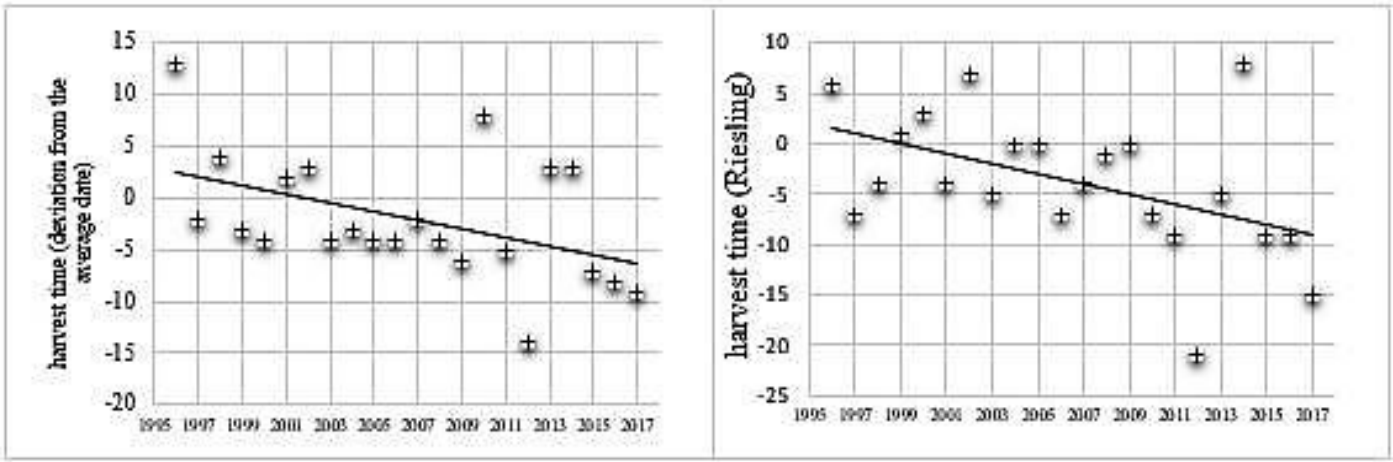

Figure 7. The mean harvest time of all varieties (left) and Riesling (one of the most sensitive varieties) (right) in Sopron and Zala since 1996 (deviaton from the average date, sd $=4.74$ )

This is due mainly to the blocking anticyclones in summer. Some climatic scenarios show that in the Euro-Atlantic areas such situations will arise more frequently during the whole year, particularly in winter and in summer (Mokhov et al., 2014). As a result of the increasing anticyclonic situations, during the 60 days preceding the harvests less precipitation is falling, the cloud cover has decreased by $8 \%$, and as mentioned previously, the number of sunshine days, excessive heat days and hot days has increased, thus the sugar accumulation and the forced ripening became faster (Hajdu and Borbásné, 2009).

The relationship $(\mathrm{r}=0.88)$ between the proportion of anticyclonic days in the 60 days preceding the harvests and accumulation of sugar in the must is significant ( $p<0.01$ ). The result of the regression calculations is $R=0.8015$. By the increase of the proportion of the anticyclonic days, the sugar accumulation in the must at the moment of the harvest is increasing. Considering the period since 1996, the number of anticyclonic days was very high in 2003, 2006, 2011, 2012 and 2017. As far as the active heat surplus is concerned, in such years higher value was registered (1280$1310{ }^{\circ} \mathrm{C}$ ), therefore the sugar accumulation and ripening were both faster, the sugar surplus (content) in the must was 55-60 g/l. In such years the precipitation during the time of the ripening (between $1^{\text {st }}$ of August and $30^{\text {th }}$ of September) lags behind the average by $31 \%$, 2012 was very dry, then the difference reached $38 \%$. Excluding 2006 (humidity was high, avg. 71-72 \%), when the amount of sugar in the must is above $17.6^{\circ} \mathrm{M}$, or considering a scale of 1 to 6 , the vintage of the red wines always scored 4 (quality) or above (high quality), on the bases of the data of Sopron and Zala winegrowers, the white varieties also score above 4 (particularly Pinot Gris (late harvest) and Riesling (dry berry selection)).

When certain wine grape varieties are investigated, it can be concluded that the anticyclonic days in the 60 days preceding the harvests had the strongest impact on the must of Blaufränkisch, Müller-Thurgau, Leányka and Zweigelt. Correlation coefficient $\mathrm{r}=0.87$. The correlation is also strong in case of Pinot Gris, Királyleányka (Pinot Gris $\mathrm{r}=0.80$ Királyleányka $\mathrm{r}=0.81$, Cabernet Sauvignon $\mathrm{r}=0.71$ (medium strong)).

Following the first frost, the leaves begin to fall as the grape plant starts to enter its winter dormancy period. 


\section{Conclusions}

Climate and its changes are the key controlling factors in grape and wine production, affecting the suitability of certain grape varieties in the studied wine-growing regions. Climate data of the last 30 years has shown that the temperatures has risen with a linear warming trend of $\sim 1.2^{\circ} \mathrm{C} / 30$ years and this affects viticulture of the Zala and Sopron wine-growing region. The increasing temperature and the decreasing precipitation have positive and negative effects in the studied wine-producing regions.

Extremities originating from the changes of temperature and precipitation can be considered beneficial regarding wine production.

A significant shift has taken place in the annual growth cycle of grapevines, budbreak begins nearly 8 days earlier, flowering 7 days and the veraison 8 days, while the harvest has been shifted to a date 11 days respect to the previous period. The time between the budbreak and the flowering has shortened by 4.5 days. The sugar degree measured at the time of the harvest is increasing by the rate of the increase of the anticyclonic days in summer and early autumn and that from 5 years 3 are either good or excellent vintages, while previously from 5 only 1 got such qualification, are all presumably among the consequences of the climatic change.

The research will be continued, extending to all wine grape varieties and a new phenological index will be formed for the winegrowers and researchers.

Acknowledgements. Supported by the ÚNKP 17-3 New National Excellence Program of the Ministry of Human Capacities.

\section{REFERENCES}

[1] Apró, M. (2016): Application and Development of Detection Methods of Grape Viruses in the Survey of Virus Infection of Vineyards. - Doctoral $(\mathrm{PhD})$ Thesis. University of Pannonia, Keszthely.

[2] Bowen, P. A., Bogdanoff, C. R., Estergaard, B. (2004): Impacts of using polyethylene sleeves and wavelength-selective mulch in vineyards. I. Effects on air and soil temperatures and degree day accumulation. - Canadian Journal of Plant Science 84(2): 545-553.

[3] Bussay, A., Szinell, Cs., Szentimrey, T. (1999): Az aszály magyarországi előfordulásainak vizsgálata és mérhetősége. Éghajlati és agrometeorológiai tanulmányok 7. - OMSZ, Budapest (in Hungarian).

[4] Carter, T. R., Parry, M. L., Porter, J. H. (2007): Climatic change and future agroclimatic potential in Europe - International Journal of Climatology 11(3): 251- 269.

[5] Clarke, O., Rand, M. (2001): Encyclopedia of Grapes. - Harcourt, New York.

[6] Cook, B. I., Wolkowich, E. M. (2016): Climate change decouples drought from early wine grape harvests in France. - Nature Climate Change 6: 715-719.

[7] Currle, O., Bauer, O., Hofäcker, W., Schumann, F., Frisch, W. (1983): Biologie der Rebe. - Meininger Verlag, Neustadt (in German).

[8] Dövényi, Z. (2010): Inventory of Microregions in Hungary, $2^{\text {nd }}$ ed. - MTA (Hungarian Academy of Sciences), Budapest.

[9] Durack, P. J., Gleckler, P., Landerer, F. W., Taylor, K. E. (2014): Quantifying underestimates of long-term upper-ocean warming. - Nature Climate Change 4: 9991005. DOI: $10.1038 /$ nclimate2389. 
[10] Fraga, H., Malheiro, A., Moutinho-Pereira, J., Santos, J. A. (2013): Future scenarios for viticultural zoning in Europe: ensemble projections and uncertainties. - International Journal of Biometeorology 57(6): 909-925.

[11] Fraga, H., Malheiro, A. C., Moutinho-Pereira, J., Santos, J. A. (2014): Climate factors driving wine production in the Portuguese Minho region. - Agricultural and Forest Meteorology 185: 26-36.

[12] Frankel, C. (2014): Land and Wine: The French Terroir. - University of Chicago Press, Chicago.

[13] Gaál, M., Moriondo, M., Bindi, M. (2012): Modelling the impact of climate change on the Hungarian wine regions using Random Forest. - Applied Ecology and Environmental Research 10(2): 121-140.

[14] Grzeskowiak, L., Costantini, L., Lorenzi, S., Grando, M. S. (2013): Candidate loci for phenology and fruitfulness contributing to the phenotypic variability observed in grapevine. - Theoretical and Applied Genetics 126(11): 2736-2776.

[15] Hajdu, E., Borbásné, S. É. (2009): Abiotikus stresszhatások a szőlő életterében. Agroinform Kiadó, Budapest (in Hungarian).

[16] Herbst, R., Herbst, S. T. (2003): The New Wine Lover's Companion. $2^{\text {nd }}$ ed. - Barrons, New York.

[17] Hlaszny, E. (2012): Early Phenological Responses of Grapevine (Vitis vinifera L.) in Kunság Wine-Growing Area Based on Plant Surveys, Weather Observations and Regional Climate Model. - Doctoral (PhD) Thesis. Corvinus University of Budapest, Budapest.

[18] Hoffmann, M., Hoppmann, D., Hannes, R. S. (2007): Einfluss der Klimaveränderung auf die phänologische Entwicklung der Rebe sowie die Säurestruktur der Trauben. - FA Geisenheim, DDW Geisenheim.

[19] Hoppmann, D. (2010): Terroir, Wetter-Klima-Boden. - Verlag Ulmer KG, Stuttgart (in German).

[20] Huglin, P. (1986): Biologieetécologie de la vigne. - Ed. Payot, Lausanne-Paris (in French).

[21] Ignaciuk, A., Mason-D'Croz, D. (2014): Modelling Adaptation to Climate Change in Agriculture-OECD Food. Agriculture and Fisheries Papers 70. - OECD Publishing, Paris.

[22] Justyák, J. (1998): Magyarország éghajlata. Climate of Hungary - Kossuth Egyetemi Kiadó, Debrecen (in Hungarian).

[23] Keddy, P. A. (2007): Plants and Vegetation: Origins, Processes, Consequences. Cambridge University Press, Cambridge.

[24] Kriszten, Gy. (1999): Tavasztól-tavaszig a szőlőben - Mezőgazda Kiadó, Budapest (in Hungarian).

[25] Kovács, E., Puskás, J., Pozsgai, A. (2017): Positive Effects of Climate Change on the Field of Sopron Wine-Growing Region in Hungary. - In: Karacostas, T. S. et al. (eds.), Perspectives on Atmospheric Sciences, pp. 607-613. Springer Atmospheric Sciences, Zürich.

[26] Lobell, D., Burke, T., Tebaldi, C., Mastarndera D. M., Falcon, P. W., Naylor, R. L. (2008): Prioritizing climate change adaptation needs for food security in 2030. - Science 319: 607-610.

[27] Maaß, U., Schwab, A. (2011): Wärmeanspruch von Rebsorten. - Klimawandel und Sortenwahl 10: 29-31 (in German).

[28] Makra, L., Mika, J., Bartzokas, A., Sümeghy, Z. (2007): Relationship between the Péczely's large-scale weather types and air pollution levels in Szeged, Southern Hungary. - Proceedings of the $8^{\text {th }}$ Hellenic Conference on Meteorology, Climatology and Atmospheric Physics C: 135-145.

[29] Mesterházy, I., Mészáros, R., Pongárcz, R. (2014): The Effects of Climate Change on Grape Production in Hungary. - Időjárás 118(3): 193-206. 
[30] Mokhov, I. I., Timazhev, A. V., Lupo, A. R. (2014): Changes in atmospheric blocking characteristics within Euro-Atlantic region and Northern Hemisphere as a whole in the $21^{\text {st }}$ century from model simulations using RCP anthropogenic scenarios. - Global and Planetary Change 122: 265-270.

[31] Mozell, M. R., Thach, L. (2014): The impact of climate change on the global wine industry: Challenges \& solutions. - Wine Economics and Issues 3(2): 81-89.

[32] Mullins, M. G., Bouquet, A., Williams, L. E. (1992): Biology of the Grapevine. Cambridge University Press, Cambridge.

[33] Orlandi, S., Di Stefano, V., Lucchesini, P., Puglisi, A., Bartolini, G. (2009): Current trends of agroclimatic indices applied to grapevine in Tuscany (Central Italy) - Időjárás 113(1-2): 69-78.

[34] Péczely, Gy. (2002): Éghajlattan [Climatology]. - Nemzeti Tankönyvkiadó, Budapest (in Hungarian).

[35] Puskás, J., Károssy, Cs. (2013): A bor minőség és az időjárás közötti összefüggések néhány jellemzője a Köszeg-hegyaljai borok és Szombathely 100 éves napi meteorológiai adatai alapján. - 4. Szőlő és Klíma Konferencia, Kőszeg, CD-ROM: 142-153. (in Hungarian). 